\title{
Analyze the Conceptual Understanding of Earthquakes among Geography Teachers in Ranau, Sabah
}

\author{
Soon Singh BIKAR ${ }^{1}$ \\ Universiti Malaysia Sabah \\ MALAYSIA
}

\author{
Zulfikar RABE ${ }^{2}$ \\ Universiti Malaysia Sabah \\ MALAYSIA
}

\author{
Balan RATHAKRISHNAN ${ }^{3}$ \\ Universiti Malaysia Sabah \\ MALAYSIA
}

\begin{abstract}
${ }^{1}$ Corresponding author: Dr.. Universiti Malaysia Sabah, Faculty of Psychology and Education, Kota Kinabalu, Sabah, MALAYSIA. soonbs [at] ums.edu.my. ORCID: 0000-0001-7272-484

$2 \mathrm{Mr}$.. Universiti Malaysia Sabah, Faculty of Psychology and Education, Kota Kinabalu, Sabah, MALAYSIA. zulpkar91 [at] gmail.com. ORCID: 0000-0003-3010-7573

${ }^{3}$ Assoc.. Prof.. Universiti Malaysia Sabah, Faculty of Psychology and Education, Kota Kinabalu, Sabah, MALAYSIA. rbhalan [at] ums.edu.my. ORCID: 0000-0003-4136-4495
\end{abstract}

\section{Abstract}

The Sabah Meteorological Department (2015) reports that in the next 20 years a large-scale earthquake will hit Sabah. This inevitability means that the local community needs to be sufficiently informed so as to be prepared for disaster. Formal education can be used as a medium for conveying knowledge about earthquakes. However, scholars believe that to impart such knowledge, teachers' understanding of earthquake concepts needs to be evaluated as they are the main sources of information on the topic. This study applied a concurrent triangulation mixed-method model to explore the understanding of earthquake concepts among Geography teachers in Ranau. The quantitative data were collected through a survey, while the qualitative data were collected through teachers' interviews. Random sampling methods were used to select 80 Geography teachers from nine secondary schools in Ranau, Sabah. Of these, 18 were selected through the purposive sampling method for interviews. Triangulation of quantitative and qualitative data revealed that the level of understanding of the earthquake concept and the level of readiness for an earthquake disaster is moderate. The findings also indicated that female teachers are more aware of the concept of earthquakes and male teachers are more prepared for them due to physical and emotional factors. Furthermore, senior teachers are more aware of the concepts and are more prepared for the earthquake than their junior colleagues. Finally, the findings of this study contribute to the science of earthquake education in Malaysia and aid Geography teachers, as well as assisting schools to help teachers improve their understanding of earthquake concepts.

\section{Keywords}

Earthquake, Concept Understanding, Geography Teacher, Ranau

To cite this article: Bıkar, S. S.; Rabe, Z;; Rathakrishnan, B (2021). Analyze the conceptual understanding of earthquakes among geography teachers in Ranau, Sabah. Review of International Geographical Education (RIGEO), 11(2), 429-448. doi: 10.33403rigeo.780909 
Earthquake disasters have a lot of negative effects on our lives. As well as causing fatalities, they can destroy property. They are typically associated with fires, landslides, floods, outbreaks, and social panic, which eventually lead to adverse consequences (Zhang, Weng \& Huang, 2018). Education is seen as the best medium to help reduce the risk of building disaster resilience for people in areas vulnerable to earthquakes (Shiwaku, Ueda \& Shaw, 2016). Torani, Majd, Maroufi, Dowlati \& Sheikhi (2019) also proclaim that a good understanding of earthquakes and preparation is important in the context of earthquake education. Communities that learn more about the nature and occurrence of earthquakes (what an earthquake is like, how it happens and how to protect oneself in the event of one), can be considered to be 'earthquake aware'. Such education is necessary to ensure that communities are better prepared to deal with these events in the future (Lownsbery \& Flick, 2020). Based on these explanations, it is clear that efforts to improve understanding need to be made in schools, as they are strategic institutions that play an important role in preventing and mitigating the effects of disasters. Moreover, comprehensive knowledge and understanding further enhances environmental sustainability awareness (Hanifah, Mohmadisa, Yazid, Nasir, Samsudin \& Balkhis, 2020). Researchers suggest that learning about earthquake disasters can be integrated in certain subjects such as Geography and Science or used as one of the new subjects to teach natural disasters.

Scholars are also proposing to use formal education as a medium for communicating knowledge of earthquake disasters. This is because various studies have shown that the involvement of school children in earthquake disaster education activities can minimize some of the risks involved and promote resilience after a disaster. The studies of Simsek (2007) and Wachtendorf, Brown \& Nickle (2008) reveal that children can make more realistic decisions in the event of an earthquake. In addition, through appropriate education, children living in high-risk areas will have a better sense of threat and more confidence in decisionmaking and greater knowledge of proper protection behaviors (King \& Tarrant, 2013; Mutsau \& Billiat, 2015). However, scholars argue that to educate and convey knowledge of earthquakes, teachers' understanding of the concepts involved need to be better, as they are responsible for delivering the disaster sciences which more specifically refer to the causes, types of earthquakes and the processes involved in their formation should be considered directly to students (Panic, 2013; Ganpatro, 2014; Tuswadi \& Hayashi, 2014; Mutch, 2015).

Understanding concepts is really what one knows and understands about them and their relationship to content (Ministry of Education New Zealand, 2009). There have been many studies conducted to examine mastery and understanding of concepts among teachers (Lane, 2008; Lane \& Coutts, 2012; Kapucu \& Yildirim, 2012; Preston, 2014; Lane, 2015; Kazunga \& Bansilal, 2017). However, the contents of earthquakes are included in the Geography curriculum in Malaysia but are not discussed comprehensively. Therefore, there is still a lack of conceptual understanding of earthquakes among teachers in Malaysia.

Scholars agree that a clear understanding of the subject matter is crucial for teachers. For example, Fulmer (2013) states that understanding concepts is crucial if teachers are to convey knowledge more effectively. Inaltun (2015) also argues 
Bikar, S. S.; Rabe, Z.; Rathakrishnan, B (2021). Analyze the conceptual understanding of...

that a deeper understanding can reduce misinterpretations of real meaning in a content context. This is supported by Hanson (2016) who concludes that teachers need to pay attention to all relevant science concepts before introducing the topic for students to excel in the classroom. Therefore, teachers' understanding of the concepts of specific topics in the syllabus is important to facilitate student learning (Shulman, 1986).

\section{Problem Statement}

The Malaysian state of Sabah has experienced a series of earthquakes since 1897. The summary of earthquake events is as shown in Table 1.

Table 1

Earthquake Series in Sabah

\begin{tabular}{|l|l|l|}
\hline Years & Location & Scale \\
\hline 1897 & 100 km outside Sabah & 8.7 Magnitude \\
\hline 1976 & Lahad Datu & 5.6 Magnitude \\
\hline 1989 & Ranau & 5.6 Richter \\
\hline 1991 & Ranau & 5.1 Richter \\
\hline 2005 & Ranau & 4.1 Richter \\
\hline 2005 & East Tawau & 5.8 Richter \\
\hline 2010 & North EastRanau & 2.6 Ritcher \\
\hline 2011 & Lahad Datu & 3.3 Ritcher \\
\hline 2011 & Tongod, Sandakan & 4.0 Ritcher \\
\hline 2012 & Kunak & 3.7 Ritcher \\
\hline 2013 & North coast, Kudat & 3.6 Ritcher \\
\hline 2014 & Banggi Island, Kudat & 4.4 Ritcher \\
\hline 2015 & Ranau & 5.9 Ritcher \\
\hline 2018 & Ranau & 5.2 Ritcher \\
\hline
\end{tabular}

Source: Malaysian Meteorological Department (2018)

The chronology of earthquakes in Table 1 shows that Sabah has been subjected to a number of earthquake incidents, especially since the turn of the 21st century. In 2015, a Richter 5.9 magnitude earthquake hit the Ranau area. This was followed by a 5.2 magnitude earthquake on March 08, 2018, again centered on Ranau. Not surprisingly, this has caused concern among people living in the vicinity of Mount Kinabalu. In view of the regularity of earthquake occurrence, the Malaysian Meteorological Department has predicted that another large-scale earthquake will hit Sabah within the next 20 years.

This likely scenario shows that the local community needs to be educated to be ready for disaster. Chen, Yu \& Chen, (2012) emphasize that teachers' understanding of earthquakes should be reviewed and enhanced if necessary, to ensure that they are fully prepared to pass on their knowledge to students. Hence, understanding of the earthquakes which more specifically refer to the causes, types of earthquakes and the processes involved in their formation should be considered. Several quantitative studies have also shown that understanding earthquake concepts is important to schoolteachers (Simsek, 2007; Mutch, 2015; Kaya \& Aladag, 2017). For example, a study by Simsek (2007) has shown that 
teachers (33\%) are one of the primary sources of students' knowledge of earthquakes. Moreover, the study of Kaya \& Aladag (2017) found that teachers who have an in-depth conceptual understanding of earthquakes can help students configure the concept of earthquakes in their minds and be able to make connections between concepts correctly.

In this context, researchers argue that Geography teachers are important individuals because they are the key agents in the science of earthquake disasters in Malaysian secondary schools. Geography teachers are the most suitable individuals for teaching and learning sessions in schools especially in the classroom (Taylor, 2011). In addition, the topic of earthquake disasters is included in the syllabus of Geography subjects taught in the classroom. In fact, Geography teachers are responsible for helping students identify physical, human and natural phenomena in Southeast Asia, Asia and the world, which is one of the main objectives of Malaysian KSSM Geography (Curriculum Standard Documentation and Assessment, 2015).

Unfortunately, teachers still do not understand the concept of earthquakes fully and are not prepared to deal with earthquakes. The study by Singh et al. (2018) conducted in Sabah shows that almost 90 percent of teachers who teach in earthquake-prone areas have a simple understanding of the concept of earthquakes and only modest knowledge of the impacts of these disasters. Various studies reveal that the knowledge and practices of male and female teachers on understanding the earthquake concept and disaster management are at an unsatisfactory level and need to be improved. Furthermore, the findings of this study are in line with those conducted overseas (Sozen, 2019; Panic, 2013; Tuswadi \& Hayashi, 2014; Ganpatrao, 2014; Mutch, 2015; Ersoy \& Kocak, 2015; Kaya \& Aladag, 2017; Lehane \& Bertram, 2016; Bulunuz \& Jarrett, 2009).

This unsatisfactory situation results in information on earthquakes being delivered inaccurately and ineffectively to students in the classroom. Teachers who have a better understanding of the teaching concepts can reduce misconceptions among students (Lane, 2015: Ersoy \& Kocak, 2015: Kaya \& Aladag, 2017). Lownsbery \& Flick (2020) state that students often seek information through online sources and this can foster naive concepts. Understanding the causes, types of earthquakes and the processes involved is paramount.

Tuswadi \& Hayashi (2014) states that teachers' lack of understanding to inculcate it is due to limited teacher training. Thus, special training is required (Johnson, 2013; Wright \& Wordsworth, 2013; Mutch, 2015). Such studies conducted both domestically and internationally are common. However, there are none that focus on teaching about earthquakes. Consequently, this study attempts to ascertain the level of understanding of concepts on earthquakes among geography teachers, as they are the key communicators of teaching and learning sessions in schools, especially in the classroom (Dorasamy, Raman \& Kaliannan, 2013; Ohnishi \& Mitsuhashi, 2013; Panic, 2013; Taylor, 2011; Shiwaku \& Shaw, 2016). It is, therefore, in this study, the researcher will examine the level of understanding of the concept of earthquakes which refers to the mastery of concepts, cause, types, processes and effects of earthquakes and differences in gender and period of teaching. The researchers adopt the definition of Conceptual 
Bikar, S. S.; Rabe, Z.; Rathakrishnan, B (2021). Analyze the conceptual understanding of...

Understanding of Earthquakes given in Spittal, Walkey, Mcclure, Siegert \& Ballantyne (2006).

\section{Theoretical Framework}

The objective of this study was to study the conceptual understanding of earthquake concepts among Geography teachers. In this context, Pedagogical Content Knowledge (PCK) was used as the main source of reference for studying the concept of earthquakes and the provision of geographic teachers to deal with earthquakes.

The theory used in this study is based on explanations and research on the theory of pedagogical content knowledge (PCK) developed by Shulman (1986): He defines this theory as a teacher's understanding of learning as well as a methodology for specific topic concepts to make it easier for students to comprehend. Lane $(2008 ; 2012 ; 2015)$ concludes that PCK is important for teachers. For example, the results of Lane and Coutts's study (2012) show that Australian high school geography students have a variety of alternative concepts relating to the topic of tropical cyclones. He said that Geography teachers should first study before gaining a deep understanding of a topic of study. This is important so that teachers are cognizant of alternatives to the right concepts when teaching students. Lane's (2015) study also said Geography teachers with deep knowledge and understanding of the syllabus content of a topic helped to reconstruct alternative concepts that students often develop.

Several studies on PCK in relation to science and mathematics subjects have also shown that it is important for teachers to ensure effective teaching and learning (Lane and Coutts, 2012; Kratz \& Schaal, 2015; Lehane \& Bertram, 2016; Ayers, 2018; Worden, 2018). For example, Lane and Coutts (2012) concluded that effective geography teachers need to be equipped with a high level of pedagogical content including subject knowledge to make understanding of each lesson concept easy. In addition, the findings of See (2014) reveal that teachers in Malaysia who have been formally educated are likely to have a higher pedagogical content knowledge and to be more capable of teaching lesson concepts effectively.

In the context of an earthquake, teachers' comprehensive understanding of key concepts will influence the level of teacher preparation for an earthquake (Chen et al., 2012). The teacher is then able to teach students about the occurrence of earthquakes and how to prepare for earthquakes as they are the ones who have experienced the trauma associated with an earthquake. Toprak-Dereli \& SavaşclAçıkalın (2018) explains that students are not fully aware of earthquake concepts and have formulated many alternative concepts. Lownsbery \& Flick (2020) assert that students often find out about earthquakes through inaccurate online sources. Therefore, teachers need to understand the important concepts about earthquakes, such as the causes, types, scale and effects in more depth.

Based on the above explanations, the application of PCK is likely to have a positive impact on teachers and students in all subjects. Thus, it is an appropriate approach to guide researchers in assessing whether geography teachers understand earthquake disaster concepts well. 


\section{Methodology}

\section{Research Design}

This study employs a mixed-method research design, namely the Convergent Parallel Design (concurrent triangulation mixed-method) to address the research questions as shows in figure 1.

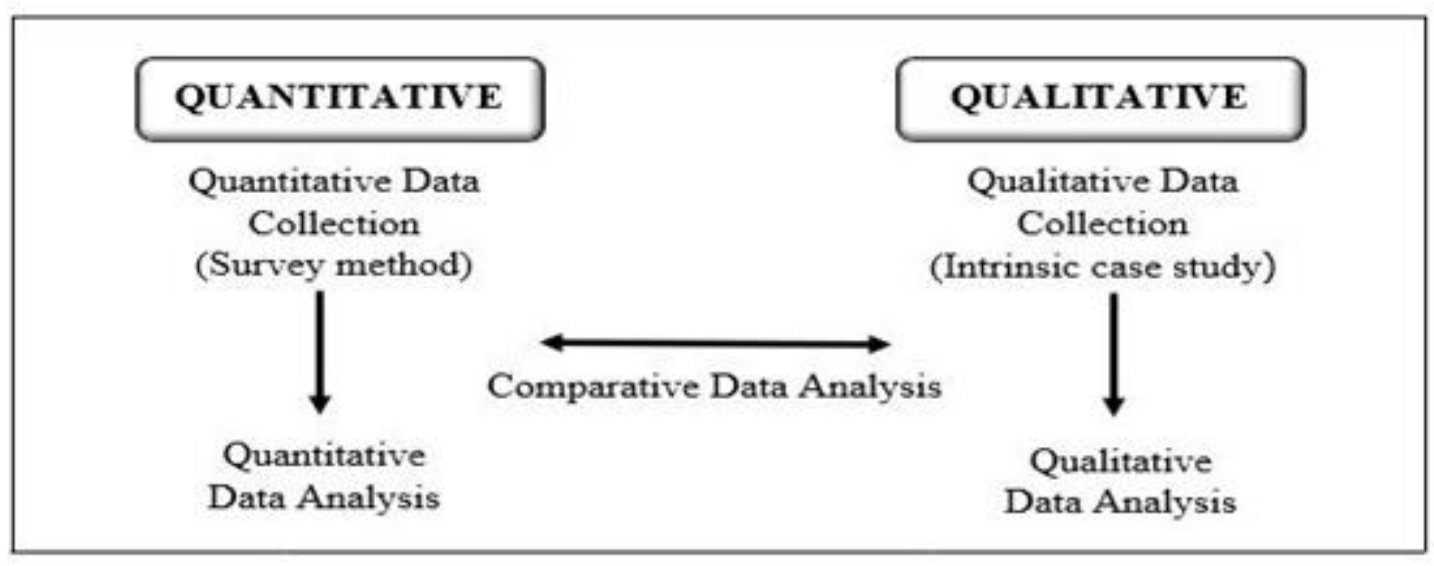

Figure 1. The convergent parallel design

This study uses the Convergent Parallel Design (concurrent triangulation mixed-method design) which is a mixed-method research design to address the research questions. According to Creswell (2012), this design is used for two main reasons which are that data collected from supplies works to offset the weaknesses of the other form and that a more complete understanding of a research problem results from collecting both quantitative and qualitative data (Singh, Rathakrishnan, Sharif, Talin \& Eboy, 2016). This mixed-method research design gives equivalent needs to both forms of data, the collection of which were undertaken simultaneously during the research. In the interpretation section, not only the findings were compared and triangulated, but also the data collected was also separately analyzed. In the context of this study, the researcher uses the first method which is quantitative and qualitative findings are described separately.

\section{Quantitative Research Design}

This study used the survey method to obtain quantitative data. The rationale for using surveys is that they can provide accurate, reliable, and valid data that can measure many variables (Neuman, 2014, p.317). It is also a suitable method for answering research questions that have been formulated by the researcher (Rathakrishnan, Molugulu, Parasuraman \& Narasappa, 2012: Rathakrishnan, Rahim, Singh \& Jaafar, 2017). The researcher used a cross-sectional survey design in conducting this study, as according to Creswell (2012), it enables researchers to collect data conveniently at one time. In this case, a survey questionnaire was distributed to all the geography teachers named as respondents.

The study population consisted of geography teachers from the 11 secondary schools in the Ranau District in Sabah which were badly affected by the earthquake in 2015 and 2018. The population of Geography teachers in these 11 schools is 100. Based on the sample setting table presented by Krejcie \& Morgan (1970) and 
supported by Cohen, Manion and Morrison (2001), Gay and Airasian (2003), a sample size of 80 was considered sufficient from a population of 100 . Random sampling was employed to select 80 teachers for quantitative research design data collection.

\section{Qualitative Research Design}

This study employed an intrinsic case study research design. The researcher chose to use an instructional case study to gain a deeper understanding of the issues under study (Bikar, Sharif, Talin \& Rathakrishnan, 2020). In this context, the researcher wished to gain a deeper appreciation of the level of understanding about earthquake concepts among Geography teachers in Ranau, Sabah.

Purposive sampling methods were employed for qualitative data collection. Two Geography teachers from each school were selected for interviews. A total of 18 teachers were interviewed.

\section{Instruments}

This study used questionnaires as a research instrument. Specifically, the Earthquake Preparedness Scale (ERS) developed by Spittal et al. (2006) was used to assess the level of understanding of earthquakes among geography teachers. The instrument consisted of 21 items using a 7-point scale ranging from scale 1 (much unprepared) to scale 7 (very good). The questionnaire consisted of five main parts that needed to be answered by the respondents. Part A dealt with demographics relating to gender and the teaching of geography. Section B had 10 questions designed to measure teachers' understanding of earthquake concepts.

Qualitative data were obtained through semi-structured interviews, which required all respondents to answer the same questions to determine the level of understanding of earthquakes and the level of readiness before, during and after such an event. The interviews were conducted on a one-to-one basis in the school administrative meeting room. Each interview session began with a brief description of the structure of the interview to be conducted and ended with the researcher thanking the individual for their participation and ensuring the confidentiality of their responses. Every interview session lasted between 50 and 60 minutes and was audiotaped.

\section{Quantitative Data Analysis}

In this study, a parametric statistical test was used to analyze the quantitative data. Normal distribution and homogeneity of variance calculations were done to ensure all the variable scores in this study met the general assumptions for a parametric test. The test revealed that the variable scores in this study were acceptable. This shows that the sample from which the score was obtained came from a population of equal variance and was normally distributed. T-test and OneWay ANOVA were used to test the study hypotheses.

\section{Qualitative Data Analysis}

The data analysis used in this study was thematic. Clarke \& Braun (2013) define thematic analysis as a way of identifying and analyzing patterns in qualitative data. 
According to Clarke \& Braun (2013), there are six steps involved in thematic analysis, which do not necessarily have to be linear. In this study, the researcher collected qualitative data namely interview transcriptions and recordings of respondents' responses during the interviews. This was to expose researchers directly to raw data; to allow them to read and reread the data (and hear the audio recording data at least once, if applicable); and to record any initial analytical observations. The second step was the coding process. The researchers used open coding to build the categories of code identified in the first phase. All code items were given equal attention during the encoding process. In fact, researchers used NVIVO applications that allow researchers to generate a lot of initial code for potential themes and patterns by marking and naming text options in each data item. This can help the researcher to understand the problems related to the research question. In the third phase - identifying the theme - all the initial codes built into the open coding process were improved, while in the fourth or theme review phase revisions were made to all the early themes. Particular attention was paid to internal homogeneity (data coherence and meaningfulness in each theme) and external homogeneity (clarity of data between themes). In the penultimate or fifth phase, researchers examined the validity of the themes in the context of the whole set of data by repeating the process of data extraction and theme examination. The researcher ensured that the themes accurately represented the data set by identifying similarities and contrasts between the themes, before revising the final set to ensure that they were consistent with the research questions. The results of the analysis are reported in the sixth phase based on the themes by referring directly to the data set. Finally, the researcher triangulated the qualitative findings quantitatively to gain a deeper understanding of the overall findings.

\section{Findings}

\section{Respondents Profile}

A total of 80 Geography teachers were selected for this study. The age of the respondents ranged from 30 to 50 years. Fifty-nine $(73.8 \%)$ of the respondents were female and twenty-one (26.3\%) were male. 17 respondents $(21.5 \%)$ had less than five years of teaching experience. 43 respondents (53.8 5) have teaching experience for six to nine years and 20 respondents (25\%) have teaching experience for more than ten years.

\section{Levels of Conceptual Understanding of Earthquake among Geography Teachers}

Quantitative analysis. For the calculation of the level of conceptual understanding scores, researchers summed up the overall score from the level questionnaire items answered by the respondents. The minimum score of this earthquake conceptual understanding item score is 13 (1 x 13), while the maximum score is 91 ( $13 \times 7)$. The researcher used the formula used by the previous researcher, namely Spittal et al. (2006), Henson (2015), Kendall (2016) and Singh et al. (2018) to classify and interpret concept comprehension scores into three levels, namely low medium and high The value of this score category is used 
Bikar, S. S.; Rabe, Z.; Rathakrishnan, B (2021). Analyze the conceptual understanding of...

to determine the frequency, percentage and mean for the respondents' level of earthquake conceptual understanding.

Table 2 shows that 15.0 percent of Geography teachers in Ranau have a low level of conceptual understanding of earthquakes, while 56.3 percent have only a moderate level of understanding. Only 28.7 percent of the teachers have a high level of understanding of earthquakes.

Table 2

The Level of Conceptual Understanding of Earthquake among Geography Teachers $(N=80)$

\begin{tabular}{ccc}
\hline Level & Frequency & Percentage (\%) \\
\hline Low & 12 & 15.0 \\
Moderate & 45 & 56.3 \\
High & 23 & 28.7
\end{tabular}

Therefore, it can be concluded that the quantitative data analysis shows that the level of conceptual understanding of earthquake among Geography teachers is moderate.

Qualitative analysis. The qualitative data analysis yielded five main themes, namely definition, scale of power, cause of occurrence, earthquake prediction and earthquake impact.

The first theme for analysis was the definition of an earthquake: 13 out of 18 teachers interviewed were able to provide an accurate definition of the earthquake. For example, respondent 1 stated:

"The experience and knowledge that I am a teacher of so little ahhh is an influence also sometimes I have read with the boy okay this earthquake is ahh movement ahhh the surface of the earth where it occurs when the plates of the plate plate shift around each other and the energy stored in the crust of the crust when it escapes it is what causes the earthquake and it is known as an earthquake."

On the other hand, knowledge of the scale of the earthquake strength was relatively modest based on the analysis of the interviews, with only 9 out of 18 teachers able to demonstrate understanding. For example, respondent 13 stated: "The scale of the recorder, the scale of this recorder is one of the units of measure for earthquake strength ranging from scale 1 to scale $10 "$.

In addition, the interviews also revealed that the level of understanding of the next theme, the causes of earthquakes, was modest, with only 9 out of 18 teachers able to state the exact causes. For example, respondent 13 said:

"As a result of movement in the crust. Ok where in the crust there is what we call a mantle and in geography we also learn that this world is made up of plates with compression, tension and this process goes on until there is an incident called a quake." 
In relation to the theme, impact of the earthquake 18 out of 18 teachers interviewed said the apparent effects of the earthquake were many cracks in the area of the earthquake. For example, respondent 10 stated:

"The 1992 earthquake only caused cracks in the teachers' housing area. However, an earthquake in 2015 also have caused a huge impact on the school and where I live. I was at home at that time and felt a large tremor and cracks in the Wall of 30 inches."

Finally, the analysis showed that only 10 of the 18 teachers interviewed said that the anticipated earthquake was due to a large earthquake following Ranau. For example, respondent 5 stated:

"Yes, after that, the incident occurred on the quake following a hundred thousand times stronger and it was normal for him to go to bed at night, but he was not strong. The house, among the cement in the village was broken."

Overall, it can be concluded from the analysis of interviews based on the five main themes that the level of understanding of earthquake concepts among geography teachers in Ranau is moderate. The results indicate some variation in the level of understanding of the teachers across the five themes. Teachers are more knowledgeable about the definition of an earthquake and the impact of an earthquake than any of the other themes.

Triangulation. The results of the quantitative analysis show that there are significant differences in the understanding of earthquake concepts among Geography teachers by gender. Female teachers understand the concept of earthquakes better than male teachers do. In this case, qualitative data analysis also shows similar results. The results of the interviews show that more female teachers than male teachers respond well to the five main themes. In this context, the researcher believes female teachers have better memories and higher cognitive abilities than their male colleagues based on the responses and detailed descriptions of four of the five main themes. They obtain earthquake-related material through various media such as the internet and scientific books. This, in turn, led them to have a better understanding of earthquake concepts than male teachers.

\section{Differences in Conceptual Understanding of Earthquakes among Geography Teachers according to Teaching Period}

Quantitative data analysis. Table 3 analyses differences in understanding of earthquake concepts based on the teaching period. Based on these criteria there was a significant mean difference $\mathrm{F}(2,77)=17.9, \mathrm{P}<0.05$ understanding of earthquake concept according to teaching period. This is because the p-value is less than the alpha value (0.05). 
Bikar, S. S.; Rabe, Z.; Rathakrishnan, B (2021). Analyze the conceptual understanding of...

Table 3

One-way ANOVA Earthquake Conceptual Understanding Based Teaching Period $(N=80)$

\begin{tabular}{llllll}
\hline & Sum of Squares & df & Mean Square & F & P \\
\hline Between & 9.011 & 2 & 4.505 & 17.937 & .000 \\
Group & 19.341 & 77 & .251 & & \\
Within Group & 28.351 & 79 & & & \\
Total & & & & & \\
\hline
\end{tabular}

Qualitative data analysis. The analysis shows that there are differences in conceptual understanding in relation to the first theme. 20 Geography teachers with 10 or more years of teaching experience were able to define earthquakes more clearly than those with less than 10 years in teaching. This can be seen from the statement of Respondent 6: "The quake was caused by a collision with the plate caused by the crust, so what is its name, it is related to the movement inside the crust itself which is associated with extremely hot temperatures."

In relation to the second theme, five out of 11 teachers who had been teaching between six and 10 years were able to articulate and explain the Richter scale. Respondent 8, with teaching experience of 10 years stated:

"We have learned about the Richter scale. It is a seismic scale system developed to provide a number to represent the energy released during an earthquake. I was understood by a professor from University Malaysia Sabah who said the 2015 earthquake in Sabah which was 5.9 was considered the strongest because we recorded numbers up to the Richter scale 7."

Meanwhile, there is a difference in the third theme, which shows that geography teachers who have been teaching between 1 to 5 years do not fully understand the cause of earthquakes. For example, Respondent 15 explained: "Ok, ermm, the cause of the earthquake is..ermm.. let me think first the cause of the earthquake, usually, someone said something happened from the sea, he also did, mobile, underground movement which is the underground movement."

In addition, there was no difference in understanding in relation to the fourth theme, the impact of the earthquake. Analysis shows that all the Geography teachers interviewed were able to describe the effects of earthquakes in detail. For example, respondent 17 who taught for 5 years stated:

"Based on my experience, the impact of the earthquake in Ranau in 2015 is that most teachers and school buildings cracked and some buildings are not suitable to be used again. In addition, the earthquake also left a deep impact on the emotions of school people, especially students. There are teachers and students who are traumatized."

Finally, the analysis also shows that there is no difference between all Geography teachers in terms of teaching time regarding the theme of the earthquake.

Based on the analysis of the interview findings, the researchers concluded that there was a difference in earthquakes conceptual understanding in terms of teaching time among Geography teachers in Ranau, specifically between those with 
10 or more years of teaching experience and those with only serve one to five and 6 to 9 years' experience. Teachers who have a longer teaching period are better able to understand and explain the five main themes used for the study.

Triangulation. The results of the interviews show that teachers with 10 years experience and above can provide good and accurate information. In addition, they are also able to provide in-depth details about the five key themes. Researchers think that this is because they have been teaching the topic of earthquakes for a long time and have consolidated their understanding of earthquake concepts. In contrast, qualitative data analysis shows that teachers who have only one to five years of teaching experience provide only basic and brief answers. Researchers think this is because they lack experience in teaching earthquake topics in the classroom. This, in turn, causes them to lack sufficient understanding of earthquake concepts.

\section{Result and Discussion}

This study was undertaken to achieve the objectives and answer the research questions that have been developed in relation to the conceptual understanding of earthquakes among geography teachers in Ranau, Sabah. Based on the findings from the quantitative data analysis, the level of understanding of earthquake concepts among geography teachers is at a moderate level. The mean score shows that only 56.3 percent of Geography teachers from Ranau have a simple understanding of earthquakes. The findings of this study are not comparable because currently insufficient studies have been conducted on the understanding of earthquake concepts among geography teachers. However, the findings of this study generally support the findings of previous studies by Simsek (2007), Mutch (2015) and Kaya \& Aladag (2017) and Singh et al (2018) that concluded that the understanding of earthquake concept among teachers is at a poor level and needs to be improved. The results of the qualitative analysis consistently support those of the quantitative study. Researchers postulate that the major factor contributing to the modest level of understanding among geography teachers is their belief that earthquakes are natural disasters. As such, there is no need for them to do further reading and obtain references: they simply depend on their textbooks and existing knowledge. In other words, they do not take earthquake risk seriously.. The researchers have found that these findings are also in line with those of previous studies on conceptual understanding of various geography topics by Preston (2014a), Preston 2015b), Lane and Coutts (2012), Reitano and Harte (2016), which show that the majority of geography teachers in Australia still have a poor understanding of concepts.

Furthermore, the triangulation of quantitative and qualitative analyses in this study (through t-test analysis) also shows that female teachers are more aware of earthquake concepts than male teachers are. This is consistent with the results of the interviews. The results of this study are not comparable to those of other studies because there are currently few studies that specifically study the understanding of earthquake concepts among Geography teachers by gender. The findings of this study generally support those of previous studies by Singh et al 
(2018), Acar, Buber \& Tola (2015), and Throndsen \& Turmo (2012). For example, a study by Singh et al (2018) revealed that female teachers have better knowledge and understanding of earthquake concepts than male teachers do. Meanwhile, Acar, Buber \& Tola (2015) reported that higher conceptual understanding led to the higher performance of female teachers compared to male teachers in tests on knowledge of the physics concepts. However, the findings of this study do not support the findings of previous studies by Kapucu and Yildirim (2012) and Inaltun (2015) who found that male teachers understand the concepts better than their female counterparts do. One explanation for this finding is those female teachers are more interested in reading materials related to earthquakes through various mediums such as the internet, social media and scientific books. Therefore, they have an adequate and deep understanding of the concept of earthquakes compared to male teachers.

This situation makes them able to teach the important concepts of earthquakes in the classroom. This view is supported by the study of Tavsanli \& Kaldirim (2017) shows that female read from various fields of specialization on a daily basis to enhance their general knowledge. From the interviews conducted, the researchers discovered that female teachers were more active in providing answers and detailed descriptions when answering questions from they also read more about earthquake-related materials through various mediums, such as the internet and scientific books. This is supported by the study of Singh et al (2018) who says that female teachers are more diligent in their search for information and have a deeper knowledge and understanding of earthquakes. This, in turn, has led them to have a better understanding of earthquake concepts than their male counterparts.

The objective of this study was also to identify differences in understanding of earthquake concepts among geography teachers based on length of teaching experience. The findings of this study indicate that there are significant differences in the understanding of earthquake concepts among geography teachers according to length of teaching period based on variance analysis. The findings of this study directly support the findings of previous studies by Rice (2010) state that teaching period influences the level of understanding of a teacher's concept of a subject.

However, very few studies have been conducted to reveal differences in earthquake concepts among geography teachers over the course of their teaching. In this context, this study revealed that senior teachers with a tenure of 10 years understood the concept of earthquakes more than novice teachers who had only taught from one to five years. The findings of this study are in line with previous studies on subjects other than geography conducted by Ewetan \& Ewetan (2015) and Kini \& Podolsky (2016). They found that schools with teachers who had taught for more than 10 years had a better understanding of the core concepts of a subject. From the results of interviews, the researchers concluded that teachers who teach six to 10 years of age can provide good and accurate information. In addition, they are also able to provide in-depth details in response to interview questions. 
On the other hand, qualitative data analysis also shows that teachers who have one to five years of teaching provide only basic and brief answers. Researchers think this is because they lack experience in teaching earthquake topics in the classroom. As a result, they have inadequate understanding of earthquake concepts. This statement concurs with Gist and Mitchell's (1992) opinion that experienced teachers can provide detailed explanations because they rely heavily on memory and interpretation of previous teaching experiences. However, the findings of this study do not support the findings of the study conducted by Johari, Ismail, Osman \& Othman (2009) and Abdul Rahim \& Abdullah (2017), who found that the extent of the teacher's experience did not influence the level of their understanding and teaching competence in the classroom.

\section{Suggestions}

This study provides new insights into the understanding of earthquake concepts and the readiness of geography teachers for earthquake disasters. The main finding of this study is that the level of understanding of earthquake concepts is still at a moderate level. This study has made a unique contribution to research into understanding about the earthquake phenomenon in Malaysia. This topic needs to be highlighted in order to focus greater attention on teaching of the earthquake sciences, principally by geography teachers. Therefore, it is hoped that this study will encourage, inspire, and provide guidance to geography teachers to improve their knowledge of earthquakes in order to teach students more effectively. In addition, it is hoped that the findings of this research will motivate the Ministry of Education Malaysia to implement programs relevant to all teachers, and especially geography teachers before focusing on earthquake education across Malaysia.

\section{Acknowledgement}

This work was supported by the Universiti Malaysia Sabah Post graduate Research Grant (GUG0256-1/2028). 


\section{References}

Abdul Rahim, N., \& Abdullah, A. H. (2017). Kesediaan Guru Matematik Sekolah Menengah dalam Melaksanakan Proses Pembelajaran dan Pengajaran Abad ke-21. In: Isu-isu pendidikan kontemporari. Universiti Teknologi Malaysia, 1, 567-584.

Acar, O., Buber, A., \& Tola, Z. (2015). The effect of gender and socio-economic status of students on their physics conceptual knowledge, scientific reasoning, and nature of science understanding. Procedia-Social and Behavioral Sciences, 174, 2753-2756. https://doi.org/10.1016/j.sbspro.2015.01.962.

Ayers, C. A. (2018). A first step toward a practice-based theory of pedagogical content knowledge in secondary economics. The Journal of Social Studies Research, 42(1), 61-79.

Bikar, S. S., Sharif, S., Talin, R., \& Rathakrishnan, B. (2020). Students' Perceptions about the Use of Minimalist Robotic Games in Geography Education. Review of International Geographical Education Online, 10(4), 584-595.

Bulunuz, N., \& Jarrett, O. S. (2009). Understanding of Earth and Space Science Concepts: Strategies for Concept-Building in Elementary Teacher Preparation. School Science and Mathematics. 109(5), 276-286.

Chen, C., Yu, K., \& Chen, M. (2012). Planning of professional teacher-training program for disaster prevention education and executing efficiency evaluation. Disaster Prevention and Management: An International Journal, 21(5), 608-623.

Chua, Y.P. (2014). Kaedah Penyelidikan Buku 1 (Vol. 3). Mc Graw Hill Education (Malaysia) Sdn. Bhd.

Clarke, V., \& Braun, V. (2013). Teaching thematic analysis: Overcoming challenges and developing strategies for effective learning. The Psychologist, 26(2), 120-123.

Cohen, L., Manion, L., \& Morrison, K. (2001). Research Methods in Education (5th ed.). Oxford: Routledge Falmer Publisher.

Creswell, J. W. (2012). Educational Research: Planning, Conducting, and Evaluating Quantitative and Qualitative Research (4th ed). Boston, MA: Pearson Education.

Curriculum Standard Documentation and Assessment. (2015). Kuala Lumpur: Malaysian Ministry of Education.

Dorasamy, M., Raman, M., \& Kaliannan, M. (2013). Knowledge management systems in support of disasters management: A two-decade review. Technological Forecasting and Social Change, 80(9), 1834-1853.

Edu, D.O., Edu, G.O., \& Kalu, I. M. (2012). Influence of academic qualification and gender on teachers' perception of difficult concepts in primary science in Ikom Educational Zone of Cross River State, Nigeria. Greener Journal of Educational Research, 2(2), 2126.

Ersoy, S., \& Kocak, A. (2015). Disasters and earthquake preparedness of children and schools in Istanbul, Turkey. Geomatics, Natural Hazards and Risk, 7(4), 1307-1336. https://doi.org/10.1080/19475705.2015.1060637.

Ewetan, T. O., \& Ewetan, O. 0. (2015). Teachers' teaching experience and academic performance in mathematics and English Language in public secondary schools in Ogun State, Nigeria. International Journal of Humanities Social Sciences and Education (IJHSSE), 2(2), 123-134. 
Fulmer, G. W. (2013). Constraints on conceptual change constraints on conceptual change: How elementary teachers' attitudes and understanding of conceptual change relate to changes in students' conceptions. Journal of Science Teacher Education, 24(7), 1219-1236. https://doi.org/10.1007/s10972-013-9334-3

Ganpatrao, J. S. (2014). Knowledge and practices of schoolteacher regarding disaster management. International Journal of Health System and Disaster Management, 2(2), 98-102. https://doi.org/10.4103/2347-9019.139055

Gay, L. R., \& Airasian, P. (2003). Educational research: Competencies for analysis and application ( $7^{\text {th }}$ ed.). Upper Saddle River, NJ: Pearson Education.

Gist, M. E., \& Mitchell, T. R. (1992). Self-efficacy: A theoretical analysis of its determinants and malleability. The Academy of Management Review, 17(2): 183- 211.

Hanifah, M., Mohmadisa, H., Yazid, S., Nasir, N., Samsudin, S., \& Balkhis, N. S. (2020). Determination of Physical Geographical Components in the Construction of Environmental Sustainability Awareness Index of the Malaysian Society. Asia-Pacific Social Science Review, 20(3), 142-152.

Hanson, R. (2016). Ghanaian Teacher Trainees' Conceptual Understanding of Stoichiometry. Journal of Education and e-Learning Research, 3(1), 1-8. https://doi.org/10.20448/journal.509/2016.3.1/509.1.1.8.

Hoque, K. E., Razak, A. Z. A., Zohora, M. F., \& Islam, R. (2013). Impact of teacher-gender on primary students' achievement: A study at Malaysian standpoint. Journal of Sociological Research, 4(1), 124-144. https://doi.org/10.5296/jsr.v4i1.3295

Inaltun, H., \& Ateş, S. (2015). Investigating relationships among pre-service science teachers' conceptual knowledge of electric current, motivational beliefs and selfregulation. Eurasia Journal of Mathematics, Science \& Technology Education, 11(6), 1657-1676.

Izadkhah, Y. O., \& Heshmati, V. (2007). Applicable Methods in Teaching Earthquakes to Children's Learning. Proceedings of Fifth International Conference on Seismology and Earthquake Engineering. Iran: International Institute of Earthquake Engineering and Seismology (IIEES).

Jensen, B., Hernandez, A. S., Knoll. S., \& Gonzalez. E.J. (2012). The Experience of New Teachers: Results from TALIS 2008. Paris: OECD Publishing. http://dx.doi.org/10.1787/9789264120952-en

Johari, K., Ismail, Z., Osman, S., Othman, A. T. (2009). Pengaruh Jenis Latihan Guru dan Pengalaman Mengajar Terhadap Efikasi Guru Sekolah Menengah. Jurnal Pendidikan Malaysia, 34(2), 3-14.

Johnson, V. A. (2013). An impact evaluation of ShakeOut, an earthquake and tsunami drill in two coastal Washington state school districts. GNS Science Report, 2013(19), 1-37.

Kapucu, S., \& Yildirim, U. (2012). Prospective physics teachers' views on their knowledge about the new concepts in Turkish high school physics curricula. European Journal of Physics Education, 3(3), 1-14.

Kaya, B., \& Aladag, C. (2017). Determining the Cognitive Structures of Geography Teacher Candidate on "Earthquake". International Education Studies, 10(1), 122-136. https://doi.org/10.5539/ies.v10n1p122.

Kazunga, C., \& Bansilal, S. (2017). Zimbabwean in-service mathematics teacher' understanding of matrix operations. Journal of Mathematical Behavior, 47, 81-95. https://doi.org/10.1016/j.jmathb.2017.05.003. 
Bikar, S. S.; Rabe, Z.; Rathakrishnan, B (2021). Analyze the conceptual understanding of...

King, T. A., Tarrant, R. A. C. (2013). Children's knowledge, cognitions and emotions surrounding natural disasters: An investigation of year 5 students, Wellington, New Zealand. Australasian Journal of Disaster and Trauma Studies, 2013(1), 17-26.

Kini, T., \& Podolsky, A. (2016). Does Teaching Experience Increase Teacher Effectiveness? A Review of the Research. Palo Alto: Learning Policy Institute.

Kratz, J., \& Schaal, S. (2015). Measuring PCK - Discussing the assessment of PCK related achievement in science teacher training. Procedia - Social and Behavioral Sciences, 191, 1552-1559. https://doi.org/10.1016/j.sbspro.2015.04.289.

Krejcie, R.V., \& Morgan, D. W. (1970). Determining sample size for research activities. Educational and Psychological Measurement, 30(3), 607-610.

Lane, R. (2008). Students' alternative conceptions in geography. Geographical education, 21, 43-52.

Lane, R. (2015). Primary geography in Australia: Pre- Service primary teachers' understandings of weather and climate. Review of International Geographical Education Online, 5(2), 199-217.

Lane, R., \& Coutts, P. (2012). Students' alternative conceptions of tropical cyclone causes and processes. International Research in Geographical and Environmental Education, 21 (3), 205-222. https://doi.org/10.1080/10382046.2012.698080

Lehane, L., \& Bertram, A. (2016). Getting to the CoRe of it: A review of a specific PCK conceptual lens in science educational research. Educacion Quimica, 27 (1), 52-58. https://doi.org/10.1016/j.eq.2015.09.004.

Lownsbery, D. S., \& Flick, L. B. (2020). Examining middle school students' knowledge and beliefs about earthquake and tsunami. Journal of Geoscience Education, 68(4), 1-13. doi:10.1080/10899995.2019.1707587.

Malaysian Meteorological Department. (2018). Seismic and tsunami hazards and risks study in Malaysia. Kuala Lumpur: MOSTI

Ministry of Education New Zealand. (2009). Approaches to Building Conceptual Understandings. (Chadwick. D, Eds.) Wellington: Learning Media Limited.

Mulilis, J. P. (1999). Gender and earthquake preparedness: A research study of gender issues in disaster management: differences in earthquake preparedness due to traditional stereotyping or cognitive appraisal of threat?. Australian Journal of Emergency Management,40(1), 41-50.

Mutch, C. (2015). Quiet heroes: Teachers and the Canterbury, New Zealand, earthquakes. Australasian Journal of Disaster and Trauma Studies, 19(2), 77-86.

Mutsau, S., \& Billiat, E. (2015). Leveraging Schools Systems as a Locus for Disaster Risk Reduction in Zimbabwe. Journal of Education and Practice, 6(29), 163-169.

Neuman, W. L. (2014). Social Research Methods: Qualitative and Quantitative Approaches ( $7^{\text {th }}$ ed.). Essex: Pearson Education Limited.

Ohnishi, K., \& Mitsuhashi, H. (2013). Geography Education Challenges Regarding Disaster Mitigation in Japan. Review of International Geographical Education Online, 3(3), 230-240.

Panic, M., Kovacevic-Majkic, J., Miljanovic, D., \& Miletic, R. (2013). Importance of natural disaster education - case study of the earthquake near the city of Kraljevo: First results. Journal of the Geographical Institute Jovan Cvijic, 63(1), 75-88. https://doi.org/10.2298/IJGI1211 
Pokharel, A., Parajuli, P., \& Parajuli, S. (2017). Knowledge Regarding Earthquake Preparedness among the People of Biratnagar Sub-Metropolis of Eastern Nepal. Birat Journal of Health Sciences, 2(2), 201-205. https://doi.org/10.3126/bjhs.v2i2.18527.

Preston, L. (2014). Australian primary pre-service teachers' conceptions of geography. International Research in Geographical and Environmental Education, 23(4), 331349. DOI: 10.1080/10382046.2014.946325.

Preston, L. (2015). Australian primary in-service teachers' conceptions of geography, International Research in Geographical and Environmental Education, 24(2), 167180. DOI: $10.1080 / 10382046.2014 .993173$

Rathakrishnan, B., Molugulu, N., Parasuraman, B., \& Narasappa, K. (2012). The Relationship of Stress, Alcoholism and Sexual Behavior with Mental Health among Secondary School Students: A Study in Sabah, Malaysia. European Journal of Social Sciences, 31(3), 376-383.

Rathakrishnan, B., Rahim, S. A., Singh, S., \& Jaafar, J. R. (2017). Job preferences among marginalised and non-marginalised youths: A multi-ethnic study in Sabah. Pertanika Journal of Social Sciences \& Humanities, 25, 55-65. Retrieved from https://www.academia.edu/25641665/Job_Preferences_among_Youth_A_Multiethn ic_Study_in_Sabah.

Reitano, P., \& Harte, W. (2016). Geography pre-service teachers' pedagogical content knowledge. Pedagogies: An International Journal,11(4), 279-291.

Rice, J. K. (2010). The Impact of Teacher Experience Examining the Evidence and Policy Implications. National Center for Analysis of Longitudinal Data in Education Research.

Rodriguez, A. G., \& Mckay, S. (2010). Professional Development for Experienced Teachers Working with Adult English Language. Caela Network Brief.

See, N. L. M. (2014). Mentoring and developing pedagogical content knowledge in beginning teachers. Procedia - Social and Behavioral Sciences, 123, 53-62.

Shiwaku, K., Ueda, Y., Oikawa, Y., \& Shaw, R. (2016). School disaster resilience assessment in the affected areas of 2011 East Japan earthquake and tsunami. Natural Hazards, 82(1), 333-365. https://doi.org/10.1007/s11069016-2204-5

Shulman, L. S. (1986). Those who understand: Knowledge growth in teaching. Educational Researcher, 15(2), 4- 14.https://doi.org/10.3102/0013189X015002004

Simsek, C. L. (2007). Children's ideas about earthquakes. Journal of Environmental \& Science Education, 2(1), 14-19.

Singh, S. B. S., Rathakrishnan, B., Kiflee, D. N. A., Talip, R., Zulfikar \& Arlyn, S. S. L. (2018). Penilaian Pengetahuan dan Kesedian Menghadapi Bencana Gempa Bumi dalam Kalangan Guru Sekolah di Ranau, Sabah. e-Bangi: Journal of Social Sciences and Humanities, 13(2), 73-88.

Singh, S. S. B., Rathakrishnan, B., Sharif, S., Talin, R., \& Eboy, O. V. (2016). The effects of geography information system (GIS) based teaching on underachieving students' mastery goal and achievement. Turkish Online Journal of Educational TechnologyTOJET, 15(4), 119-134.

Sozen, E. (2019). The earthquake awareness levels of undergraduate students. Journal of Pedagogical Research, 3(2), 87-101. https://doi.org/10.33902/JPR.2019254175 
Bikar, S. S.; Rabe, Z.; Rathakrishnan, B (2021). Analyze the conceptual understanding of...

Spittal, M. J., Walkey, F. H., McClure, J., Siegert, R. J., \& Ballantyne, K. E. (2006). The earthquake readiness scale: The development of a valid and reliable unifactorial measure. Natural Hazards, 39(1), 15-29.

Tavsanli, O. F., \& Kaldirim, A. (2017). Examining the Reading Habits, Interests, Tendencies of the Students Studying at the Faculty of Education and Analyzing the Underlying Reason behind Their Preferences. European Journal of Educational Research, 6(2), 145-156.

Taylor, M. (2011). Year 11 geography teachers' response to the Darfield Earthquake. New Zealand Geographer, 67(3), 190-198. https://doi.org/10.1111/j.17457939.2011.01211.x

Throndsen, I., \& Turmo, A. (2012). Gender differences in teachers' beliefs and primary school children's achievements in mathematics. Problems of Education in the 21st Century, 39, 159-170.

Toprak-Dereli, D., \& Savaşcl-Açıkalın, F. (2018). Middle school students' conceptual understanding of earthquakes. SHS Web of Conferences, 48, 01024. doi:10.1051/shsconf/20184801024

Torani, S., Majd, P.M., Maroufi, S.S., Dowlati, M., \& Sheikhi, R.A. (2019). The importance of education on disasters and emergencies: A review article. Journal of Education and Health Promotion, 8, 85. doi: 10.4103/jehp.jehp_262_18.

Tuswadi \& Hayashi, T. (2014). Disaster Prevention Education in Merapi Volcano Area Primary Schools: Focusing on Students' Perception and Teachers' Performance. Procedia Environmental Sciences, 20, 668-677.

Wachtendorf, T., Brown, B., \& Nickle, M. C. (2008). Big bird, disaster masters, and high school students taking charge: The social capacities of children in disaster education. Child, Youth Environments, 18(1), 456-469.

Worden, D. (2018). Mediation and development of a novice L2 writing teacher's pedagogical content knowledge of genre. Journal of English for Academic Purposes, 34, 12-27. https://doi.org/10.1016/j.jeap.2018.02.005.

Wright, S., \& Wordsworth, R. (2013). Teaching Through 10,000 Earthquakes : Constructive Practice for Instructors in a Post-Disaster Environment. International Journal of Teaching and Learning in Higher Education, 25(2), 144- 153.

Zhang, Y., Weng, W.G., \& Huang, Z. L. (2018). A scenario-based model for earthquake emergency management effectiveness evaluation. Technological Forecasting \& Social Change, 128, 197-207.

\section{Biographical Statements}

Soon Singh BIKAR is a senior lecturer of Geography Education in Faculty of Psychology and Education, University Malaysia Sabah, Malaysia. He holds a PhD in Geography Education (Macquarie University, Sydney), M.Ed. in Educational Psychology (University of Malaya) B.A. (Hons) Geography (University of Malaya) and Teacher Training Certificate (Malay study). He has seven years of experience in teaching in Primary school, eight years in secondary school and currently as a lecturer in UMS. His research interests are in mixed methods research, geographical education, applying geography Information system (GIS) in teaching geography, creativity in teaching and learning, motivation, and learning styles. He has also written a number of book chapters, among them are Matos or Reality of Integrating GIS in Geography Education in Malaysia and Dilemma in Mastering Geography 
Skills among students of rural schools in Sabah. He is an active member of National Council for Geography Education (NCGE), Mixed Methods International Research Association and Australian Association for Research in Education.

Zulfhikar RABE SINGH is a part time post graduate student at University Malaysia Sabah. He is currently teaching at Elopora Secondary School at Sandakan, Sabah. He has 5 years' experience in teaching Geography at Secondary School He is very active doing research on Geography Education His current research is on the earthquake in Malaysia.

Balan RATHAKRISHNAN is an Associate Professor in Faculty of Psychology and Education, University Malaysia Sabah. He specialized in youth and community development program in UMS. He also won World Inventor Award from Korea in 2013 in field of research and education category for social sciences. His research focuses on youth, creativity, innovation and intervention for social problems for youth. Dr. Balan Rathakrishnan obtained his degree, M.A and Ph.D (Psychology) from National University of Malaysia (UKM). He is a member of the Malaysian Institute of Management (MIM) and member of the Malaysian Institute of Human Resource Management (MIHRM)-formerly known as The Malaysian Institute of Personnel Management. Over the years, he has completed a considerable number of published researches on stress management, career development, creativity and mental health, youth problems in the national level. 